using the Conway micro-diffusion unit, and based upon the liberation of hydrochloric acid from palladium chloride by carbon monoxide, would probably be the method of choice in most clinical laboratories.

One wishes that the important question of the assay of adrenaline and noradrenaline in urine could have been discussed in the section on adrenaline assay. In recent years clinicians have shown a keen and very understandable interest in this assay, because it is a valuable diagnostic aid for investigating patients suspected of harbouring a phaeochromocytoma. While assay by the cat blood pressure technique is probably the method of choice, many laboratories have no facilities for this procedure. Colorimetric methods have been described, but only techniques involving measurement of fluorescence in ultra-violet light seem at present to be adequate.

In the section dealing with the assay of uric acid in blood no mention is made of the simple procedure of Benedict and Behre for removing the interfering substance thioneine from blood filtrates. Doubtless the authors consider this refinement unnecessary for both the methods they quote, but it should be borne in mind by all concerned with this assay.

An appendix to this book gives, with references, a list of thirty-two further methods, not included in the text. A short description of the principle underlying each of these methods is included. Finally, full indexes of authors and subjects conclude a practical and interesting volume which should certainly find a place in the laboratories of all who use colorimetric methods in clinical or biochemical work.

N. R. LAwRIE

\section{AFRICAN APHIDS}

\section{A Study of the Aphididae (Homoptera) of East} Africa

By V. F. Eastop. (Colonial Research Publications.) Pp. vi + 126. (London: H.M. Stationery Office, 1958.) 27s. $6 d$. net.

T is surprising that so little attention has been paid 1 to surveys of the aphid fauna in the tropical and subtropical countries of the world in view of the economic importance of this class of insect. This is particularly true of Africa south of the Sahara, where the fauna has never been systematically studied and where, in consequence, many of the names that have been in common use in East Africa have now been found to be wrong. Yet it is of vital importance to the economic entomologist that he should know accurately the identity of the species with which he has to deal if he is to be able to benefit from the experience of others and from what has been recorded about it. Furthermore, in recent years, the Aphididae, as proved vectors of plant diseases, have assumed an even greater economic importance.

The objects of the present work, according to the author, are to provide a means of identifying those aphids known to occur in East Africa, to make possible the identification of those species occurring in adjacent territories that are not known from East Africa at present, and finally to bring together under each species the biological data available.

The foregoing objects have been admirably achieved. The number of known species from the region has been increased from 30 to 80 , any one of which can be run down by following the keys which take one through each category of the classification down to species. Mistaken identities of some species are rectified and other species are synonymized. A new species and a new subspecies are described and recognition characters are given in the case of most species. The figures are adequate but their arrangement and that of the legends might have been improved. A list of host plants arranged alphabetically in families and of genera within families will be most helpful in providing an indication of the possible identity of an aphid species and will form the basis of a much more extended list as more knowledge is accumulated. The book is indexed and a comprehensive list of references is supplied.

This is the type of taxonomic work that is so valuable, and becoming increasingly more so, to the economic entomologist. It is the first survey of its kind made in East Africa south of the Sahara, and it should enable entomologists and agricultural officers to recognize their species accurately.

The Colonial Office is to be congratulated on promoting this study, and it is to be hoped that it will be followed by similar surveys in other areas of Africa and elsewhere. If they are all as well and carefully executed as in the present instance they will mark an important advance.

$$
\text { W. J. HALL }
$$

\section{PSYCHIATRY IN WARTIME}

\section{Psychiatry in the British Army in the Second World War}

By Robert H. Ahrenfeldt. Pp. xv+312. (London: Routledge and Kegan Paul, Ltd., 1958.) 35s. net.

R. AHRENFELDT fights once again the battles fought during the Second World War by British Army psychiatrists, "unwelcomed and regarded with suspicion, if not despised, ... to overcome prejudices, administrative resistance and executive inertia, while simultaneously caring for their patients ..." (p. 251). The brave partisan attitudes so frankly displayed in this passage pervade his book. They are not compatible with a discerning appraisal of the scientific, technical or administrative problems. Yet account should be taken of them by everyone who studies the history of Army psychiatry, or, for that matter, the development of civilian psychiatry in the years immediately following the War, because they appear to have been shared in some degree by several of his colleagues. Whether or not Dr. Ahrenfeldt wins the reader's sympathy, his book serves a useful purpose as a concise and accurate chronicle of the changes in official policies during the War years.

Let no one diminish the achievements of Army psychiatrists. A great deal was demanded of them. Equipped with the knowledge and skills acquired during their medical training and their specialist experience in hospitals and private consulting rooms, they were required to tackle not only the problems of organizing the treatment and disposal of psychiatric casualties, but also the multifarious problems of personnel and officer selection, training, discipline and morale and the management in Army units of the dull, unstable and delinquent. They had to be experts in matters lying outside their previous experience because there were no other experts. Many of the problems had been recognized in the First World War, and were noted in the report of the Southborough Committee in 1922, but the Army entered the Second 